\title{
POVEĆANJE ODRŽIVE MOBILNOSTI UPORABOM SUSTAVA PERSONAL RAPID TRANSIT 4
}

\begin{abstract}
SAŽETAK
Neupitno je da promet negativno utječe na okoliš: onečišćuje zrak, vodu, tlo, podiže razinu buke i vibracije, djeluje na klimatske promjene, ali i na ljudsko zdravlje. Povećavanjem broja motornih vozila navedeni problemi svakodnevno postaju sve veći. Stoga je prioritet brojnih prometnih organizacija i urbanih sredina pronaći načine kako reducirati broj vozila na prometnicama u surhu smanjenja zagađenja okoliša, no da pritom zadrži dosegnuti nivo mobilnosti ljudi i robe. Jedan od načina postizanja ravnoteže između smanjivanja zagađenja okoliša i povećavanja mobilnosti ljudi i robe je Personal Rapid Transit (PRT). PRT sustav je atraktivni sustav javnog gradskog prijevoza koji omogućuje neprekidnu mobilnost ljudi i robe, od točke do točke, uz minimalno zagađenje. Dosad je implementiran u nekoliko gradova i jednu zračnu luku te svojim djelovanjem potkrepljuju sve navedene prednosti u teoriji. Predloženi su brojni PRT sustavi, ali većina ih, nažalost, nije implementirana, iako je on potpuno ekološki transportni sustav te kao takav ima ogroman potencijal za rješavanje trenutačnih problema u transportu. Istodobno je i poprilično složen i sklon pogrešnom shvaćanju. PRT sustav još uvijek nije doživio svoje potpuno otkriće, a mogao bi promijeniti povijest transportnih sustava. Stoga je svrha rada ukazati na pozitivne strane PRT sustava. Navedeno je prikazano na konkretnom primjeru grada Masdara i opisano kako su se uspjeli riješiti transportni problemi i onečišćenje okoliša uz primjenu PRT sustava. Cilj rada je prikazati PRT sustav kao nov i atraktivni oblik javnog gradskog prijevoza koji može zamijeniti klasične sustave javnog gradskog prijevoza i osobne automobile.
\end{abstract}

Ključne riječi: urbane sredine, okoliš, transportni sustav, javni gradski prijevoz

\section{UVOD}

Problemi s kojima se susreću klasični sustavi javnog gradskog prijevoza traju već duži niz godina i nisu nikakva novost. No, posljednjih godina o njima se sve više govori. Kašnjenje putnika, zagušenost u prometu, nepoštovanje voznoga reda, zastarjeli vozni park samo su neki od atributa

1 Bacc. ing. traff., studentica, Veleučilište u Rijeci, Vukovarska 58, 51000 Rijeka, Hrvatska. E-mail: itomic@veleri.hr

2 Struč. spec. ing. traff., asistent, Veleučilište u Rijeci, Vukovarska 58, 51000 Rijeka, Hrvatska. E-mail: damir.pilepic@veleri.hr

3 Dr. sc., prof. v. š., Veleučilište u Rijeci, Vukovarska 58, 51000 Rijeka, Hrvatska. E-mail: ivica.barisic@veleri.hr

4 Datum primitka rada: 15. 1. 2018.; datum prihvaćanja rada: 1. 3. 2018. 
koji krase današnje sustave javnog gradskog prijevoza. Stoga je urbanim sredinama i prometnim organizacijama nametnut zadatak da osmisle noviji i atraktivniji sustav javnog gradskog prijevoza koji će povećati mobilnost ljudi bez da se zagađuje okoliš. Rješenje za navedene probleme nalazi se u sustavu javnog gradskog prijevoza pod imenom Personal Rapid Transit. Personal Rapid Transit omogućuje koristi koji današnji sustavi javnog gradskog prijevoza ne mogu pružiti urbanoj zajednici, a pritom je izuzetno ekološki osviješten, ekonomski isplativ i relativno siguran oblik javnog gradskog prijevoza.

\section{OSIGURANJE ODRŽIVE MOBILNOSTI}

Urbane sredine suočavaju se s nizom problema današnjice. lako su sve urbane sredine različite, jedan problem kod svih je isti - prometna zagušenja koja smanjuju mobilnost ljudi i robe te popratna onečišćenja okoliša uzrokovana prometom.

Mobilnost je bitan čimbenik ljudskoga života; može se reći da je mobilnost i osnovna ljudska potreba, jer ljudski opstanak i društvene interakcije ovise upravo o mobilnosti, odnosno, o sposobnosti premještanja ljudi i robe. Prometne organizacije i urbane sredine moraju osigurati mobilnost svim ljudima i nikada ne smiju težiti njezinom smanjivanju. Kao glavni cilj mobilnosti navodi se povećavanje učinkovitosti i kvalitete prometnog sustava, ali i života ljudi. Ona se sastoji od raznih političkih i projektnih promjena načina putovanja s ciljem povećanja učinkovitosti i kvalitete prometnog sustava. No, u prometnoj struci problem predstavlja neracionalno planiranje mobilnosti koje ima za posljedicu velik utjecaj na okoliš, a utjecaj prometa na okoliš je ogroman jer je promet glavni korisnik energije, što stvara velika onečišćenja okoliša (Brčić, Slavuj, 2014:315). Poznato je da promet svojim funkcioniranjem štetno djeluje na okoliš, posebno na kakvoću zraka, vode i tla, uzrokuje povećavanje i stvaranje buke i vibracija te utječe na vizualnu degradaciju prostora i narušavanje prirodne ravnoteže biljnog i životinjskog svijeta. Razvoj prometa u budućnosti utjecat će na sve veće zagađenje, odnosno pogoršanje stanja i kakvoće okoliša. Imajući to na umu potrebno je poduzeti niz odgovarajućih mjera kako bi se smanjio naglašeni negativni utjecaj prometa na cjelokupan život Zemlje (Zanzerović, Savić, 2002:1). Stoga je potrebno uravnotežiti odnos prometa i okoliša, odnosno, zadovoljiti mobilnost, a da se pritom ne onečišćuje okoliš. U posljednje vrijeme u prometnoj struci sve više pozornosti pridaje se održivoj mobilnosti. Upravo održiva mobilnost sadrži brojne strategije za poboljšanje opcija putovanja, a da se pritom ne zagađuje okoliš. Kao glavna strategija navodi se - pokretanje inicijativa za korištenje učinkovitijih i održivih opcija za svako putovanje i dostupnije iskorištavanje postojeće prometne infrastrukture (Brčić, Slavuj, 2014:3-15). Kvalitetno upravljanje održivom mobilnošću u svijetu predstavlja društveno odgovorno i ekološki osviješteno ponašanje, a ogleda se u:

- smanjenju emisije štetnih plinova

- smanjenju razine zagađenja okoliša

- smanjenju buke

- povećanju učinkovitosti goriva

- reduciranju broja vozila u prometu na cestama

- smanjenju prometnih gužvi i protočnosti prometnica i prometnog toka 
- dodjeljivanju prioriteta javnom gradskom prijevozu kao i individualnom prijevozu

- znatnim uštedama za sudionike u prometu (www.michelin.com.hr/o/odrziva-mobilnost, 10. 10. 2017.)

Svrha održive mobilnosti je da sve veću prometnu potražnju, pogotovo u vršnim periodima, riješi suvremenim strategijama upravljanja prijevoznom potražnjom. Fundamentalni cilj strategije upravljanja prijevoznom potražnjom je optimalno iskorištavanje prometne infrastrukture određene urbane sredine te reduciranje osobnih automobila na prometnicama. Kako bi se riješili problemi mobilnosti, sukladno tome i onečišćenja okoliša, potrebno je koristiti suvremena rješenja u urbanom transportu ali da se pri tome zadovolji prostorna, ekonomska, ekološka i ergonomska racionalnost a to se postiže promicanjem održivih dnevnih putovanja i korištenjem održivih oblika javnog gradskog prijevoza (Brčić, Slavuj, 2014:3-15).

\section{PERSONAL RAPID TRANSIT}

Jedno od suvremenih rješenja koji se u posljednje vrijeme sve više spominje u održivoj mobilnosti i urbanom prometnom planiranju je Personal Rapid Transit (PRT sustav). PRT sustav je atraktivni oblik javnog gradskog prijevoza koji može u potpunosti zamijeniti klasične sustave javnog prijevoza.

PRT sustav sastoji se od autonomnih vozila (engi. Podcars) koja prevoze manji broj putnika (od 3 do 6) po posebno izgrađenim vodilicama, tj. trakovima (engl. guideway) a koja su kontrolirana i koordinirana iz centralne računalne stanice. Sustav nudi osobni brzi prijevoz na zahtjev koji funkcionira na principu usluge taksija jer se vožnja odvija direktno do željene lokacije, od točke do točke, i to samo kada korisnik zatraži. No, budući da su vozila autonomna, odnosno, kreću se bez vozača, na vlastitoj infrastrukturi, ovaj prijevoz ne može se nazvati klasičnom uslugom taksijem. Sustav funkcionira tako da onemogućuje bilo kakvo presjedanje putnika i stajanje na međustanicama. Može se reći da sustav jednim dijelom spada u kategoriju sustava dijeljene vožnje (Carpooling, Carsharing i sl.) jer su PRT vozila namijenjena za prijevoz pojedinca ili skupine ljudi koji se međusobno poznaju. PRT sustav omogućava brzi prijevoz putnika u javnom prijevozu, ali uz komfor privatnosti kakvu pružaju osobni automobili. U većini slučajeva PRT sustav ostvaruje veću brzinu nego osobno vozilo. (https://www.2getthere.eu/systems/personal-rapid-transit/, 22. 10. 2017.)

Slika 1. Autonomno vozilo PRT sustava

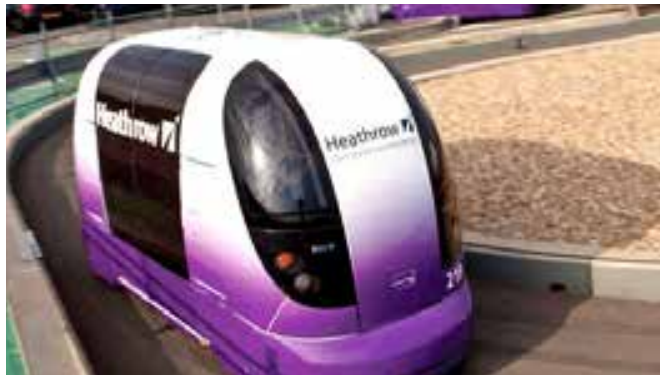

Izvor: www.govtech.com (15. 11. 2017.) 
Tri osnovna proizvođača PRT sustava su ULTra, 2getthere i Vectus. Oni pružaju mogućnost izgradnje PRT sustava prema potrebama bilo kojeg urbanog područja. Također, postoje tri osnovne vrste PRT sustava. Svi oni obično rade na vodilicama koje mogu biti na zemlji, obješene ili podzemne u tunelima. Različiti PRT sustavi omogućuju da se primijeni sustav koji najbolje odgovara urbanom razvoju grada.

Tri osnovna sustava su:

1. Otvorene vodilice; obično imaju gumene gume i rade na baterije. Nalaze se na ravnoj površini koja može ili ne mora imati bočne zidove. Neki sustavi imaju ugrađene magnete, dok drugi osjećaju svoj položaj, u odnosu na bočne zidove, pomoću lasera (Ultra i 2.getthere)

2. Unutar vodilice; u tim sustavima kotači (engl. bogey) nalaze se unutar vodilice. Horizontalni kotači su uz bočne elemente, a vodilica u osnovi upravlja vozilom. Ovi sustavi obično se napajaju linearnim indukcijskim motorima koji se također koriste za kočenje (Vectus i Skyweb Express)

3. Obješeni; kao što njegov naziv implicira, ova vrsta sustava koristi vozila koja vise s vodilica. lako to omogućuje da vozila budu vrlo lagana, to također komplicira prebacivanje. (J-Pods, SkyTran i MISTER).

(http://www.prtconsulting.com/benefits.html, 15. 12. 2017.)

Slika 2. Obješeni PRT sustav

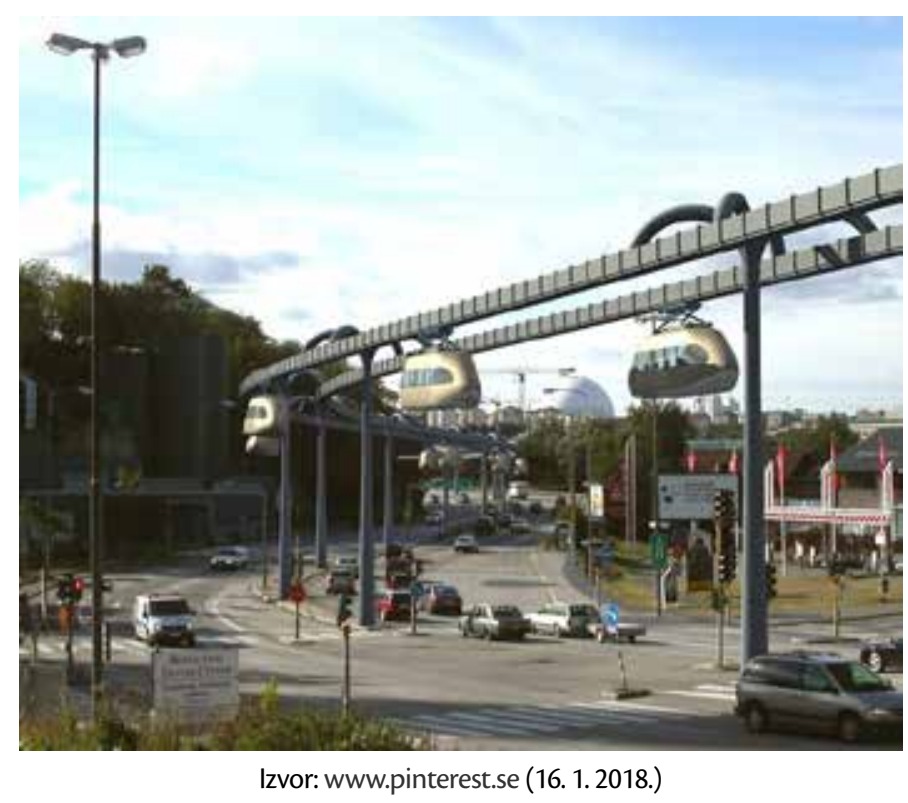

Inovativni i napredni sustav navigacije omogućava da se u bilo kojem trenutku dozna gdje se vozilo nalazi te konstantnu provjeru pozicije, pa su sudari na PRT vodilicama gotovo ne- 
mogući. PRT je sposoban raditi u ekstremnim vremenskim uvjetima, poput snijega i leda na stazama. Sam sustav funkcionira tako da se nađe skupina ljudi koja se poznaje, zatim pozove vozilo te ih to vozilo prevozi do željene destinacije, a da se pritom ne zaustavlja na usputnim stanicama $i$ kupi ostale putnike kao klasični sustav javnog gradskog prijevoza. Ako putnici izlaze na različitim stanicama, vozilo će ostaviti onog putnika čija mu je stanica najbliža te će zatim pronaći najkraći put do stanice idućeg putnika (http://www.prtconsulting.com/prt.html, 15. 12. 2017.). Bitno je naglasiti da je dostupnost vozila u prosjeku $99 \%$, stoga putnici ne moraju dugo čekati nakon što zatraže vozilo. Prosječna iskorištenost vozila obično iznosi između 1,1 i 1,5 putnika/vozilu, a vrijeme između dvaju vozila je oko tri sekunde. Posebna pozornost mora se pridavati dizajniranju PRT vozila; ona moraju biti dizajnirana da budu moderna, čista i aerodinamična. Vrata i prozori bi trebali pružati lijepe poglede iznutra, a automobili biti opremljeni punim HVAV klimatizacijskim sustavom. Vozila se mogu konfigurirati i na temelju zahtjeva klijenta. Tipični PRT automobil dugačak je $3,740 \mathrm{~mm}$, širok 2,100 $\mathrm{mm}$ i visok $2,500 \mathrm{~mm}$, a vrata su široka $900 \mathrm{~mm}$ i visoka $1,950 \mathrm{~mm}$. Vozila se mogu kretati brzinom od $70 \mathrm{~km} / \mathrm{h}$ maksimalnim opterećenjem od $2.500 \mathrm{~kg}$. Brzina rada na zavojitim trakama varira ovisno o polumjeru zakrivljenosti. Ubrzanje vozila iznosi $1,2 \mathrm{~m} / \mathrm{s}$, uz usporavanje usporavanja od $5 \mathrm{~m} / \mathrm{s}$. Pogon vozila može biti riješen na različite načine: magnetski, monorail, kablovi i sl. (https://www.railwaytechnology.com/projects/personal-rapid-transit/, 19. 12. 2017.)

\section{1 Povijest PRT sustava}

No kako je nastala prvotna ideja o PRT sustavu? Sustav je nastao oko 1953. godine kada je Donn Fichter, planer gradskog prijevoza, započeo istraživanje o PRT-u i alternativnim metodama prijevoza. Godine 1964. Fichter je objavio knjigu koja je predložila Personal Rapid Transit (PRT) u urbanim sredinama. Jedna od ključnih točaka u knjizi bilo je Fichterovo uvjerenje da ljudi ne bi napustili svoje automobile u korist javnog prijevoza, osim ako sustav ne bi ponudio fleksibilnost i veću protočnost, odnosno brže putovanje za razliku od postojećih sustava. Fichter je smatrao da fleksibilnost i performanse može pružiti samo PRT sustav. Nekoliko drugih urbanih i tranzitnih planera također je pisalo na temu PRT-a, međutim, PRT je ostao relativno nepoznat do 1966. godine kada je odjel stambenog i urbanog razvoja Sjedinjenih Američkih Država ušao u projekt osmišljavanja novih sustava za prijevoz putnika i robe. Uvjeti projekta bili su brzina, sigurnost i što manje onečišćenje zraka. Tijekom 1969. godine stručnjaci objavljuju prvi koncept PRT sustava koji se realizira tek 1975. godine i time ostvaruju sve postavljene uvjete projekta. (http://www.boeing.com/history/products/personal-rapid-transit-system. page, 19. 12. 2017.)

Trenutno na svijetu postoje četiri PRT sustava koji su u potpunosti funkcioniraju. Najstariji i najveći PRT sustav na svijetu nalazi se u Morgantownu (West Virginia) koji funkcionira od 1975. godine. Tijekom 2010. godine napravljen je mali PRT sustav u Masdaru (Ujedinjeni Arapski Emirati). Svoju operativnu snagu PRT sustav pokazuje i u zračnim lukama i to dokazuje 2011. Godine, kada se otvara u londonskoj zračnoj luci Heathrow, te dosad broji dvadeset jedno vozilo. Tijekom 2014. godine PRT sustav uveden je u južnokorejski grad Suncheon i broji četrdeset vozila. (http://www. boeing.com/history/products/personal-rapid-transit-system.page, 19. 12. 2017.) 
Slika 3. Personal Rapid Transport u zračnoj luci Heathrow (London)

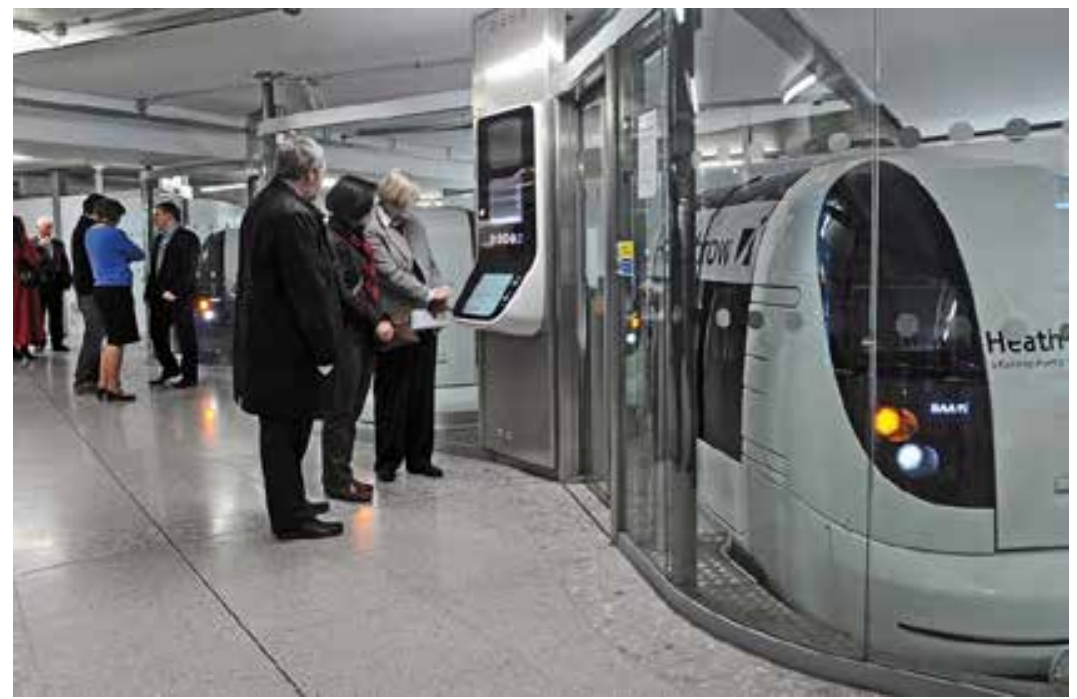

Izvor: www.arup.com (23. 11. 2017.)

\section{2 Održivi prijevoz tereta}

U gradovima je potrebno omogućiti i potreban nivo mobilnosti robe (tereta) koji je jednako bitan kao i prijevoz ljudi jer jednako uzrokuje zagušenja prometnica i onečišćenje okoliša. No, PRT sustav ima rješenje i za prijevoz tereta. Moguće je prevoziti teret pomoću sustava PRT. Takav sustav naziva se FRT (engl. Freight Rapid Transit). FRT vozila imaju iste karakteristike vožnje kao i PRT vozila koja rade na mreži. Kako FRT vozila trebaju nositi veće opterećenje, oni zapravo zahtijevaju veći motor i kočnice kako bi se osigurala jednaka ubrzanja i usporavanja. Kada se to postigne, protok na mreži ne utječe na tip vozila koje radi. Ravni stroj na kome se prevozi roba osigurava da vozilo može prevoziti bilo koju vrstu tereta pomoću spremnika. Spremnici se mogu konstruirati za opće terete, hladnjače, pakete, kontejnere i slično. Današnja ravna vozila mogu prevoziti terete do 1.600 kilograma. Najvažniji aspekt FRT sustava je, osim fleksibilne tehnologije, da mogu raditi zajedno na vodilicama s PRT vozilima (https://www.2getthere.eu/systems/freightrapid-transit/, 20. 12. 2017.) 
Slika 4. Ravni stroj u gradu Masdaru

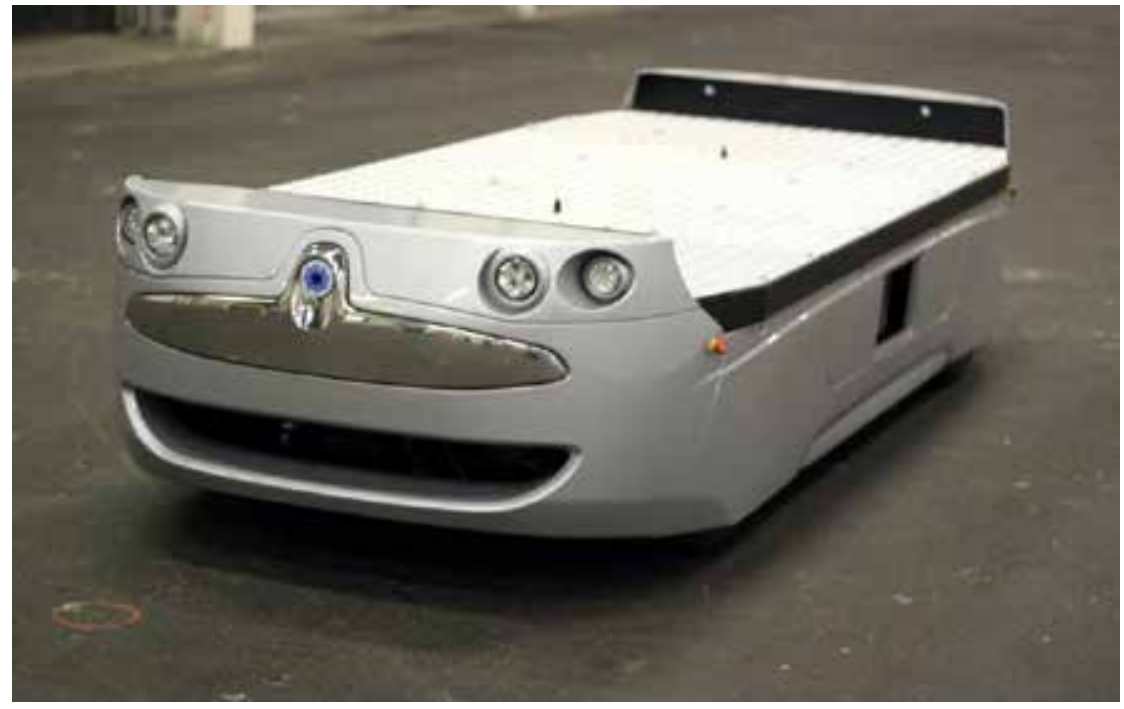

Izvor: www.prtconsulting.com (20. 12. 2017.)

\section{3 Prednosti i nedostatci PRT sustava}

Stajališta stručnjaka po pitanju PRT sustava podijeljena su. Opće stajalište nekih kritičara je da sjaj visoke tehnologije izaziva ekstravagantno trošenje i često stvara skupe nerentabilne objekte. Stručnjaci ističu da bi radije namijenili sredstva za proširenje usluga klasičnog javnog gradskog prijevoza uz zadržavanje malih vozarina nego implementirali inovativnu tehnologiju, u ovom slučaju PRT sustav. No, automatizacija kojom se odlikuje PRT sustav nudi smanjenje troškova radne snage koji predstavljaju dvije trećine operativnih troškova u javnom prijevozu. S druge strane, PRT sustav traži golemo investiranje kapitala. Prvenstvena ideja PRT-a ima za cilj pružanje usluge javnog prijevoza koja će biti konkurentna osobnom automobilu (Štefančić 2008:225). Time se vode i ključne prednosti PRT sustava, a neke od njih su:

- $\quad$ prisutan je bilo gdje u gradu

- prolazi u bilo koje vrijeme, nema stalnog voznog reda

- nema usputnih stajališta ili prekrcaja putnika

- prosječna brzina vozila je velika i prometuje samo od „vrata do vrata“

- mogućnost isključivosti korištenja vozila, znači da ne vozi druge putnike

- ekološki prihvatljiv (Štefančić 2008:225).

Kako je već naglašeno, implementiranje PRT sustava ima i drugu stranu medalje. lako sustav na prvi pogled izgleda atraktivno, sustavna tehnička analiza pokazuje manje povoljnu sliku. Neki od ključnih nedostataka koji se ističu su: 
- tehnička izvedivost: PRT sustav je nepraktičan jer zauzima velik dio prostora te ima kompliciran sustav vodilica;

- troškovi: građenje vodilica za vođenje PRT sustava, PRT stanice te sofisticirana automatizacija zahtijevaju znatne troškove ulaganja;

- opsluživanje: malena vozila učinkovita su za putovanja u području male gustoće a vrlo neučinkovita u opsluživanju velikih količina putnika, dakle, PRT sustav idealan je u stambenim predgrađima, ali neučinkovit u urbanim sredinama visoke gustoće;

- regulatorne mjere: ne postoji pravna regulativa (pravilnici, zakoni ili propisi) koji bi kontrolirali i regulirali PRT sustav;

- urbanističko uređenje: problem integriranja PRT sustava u postojeći urbani krajolik. (www.faculty.washington.edu/jbs/itrans/vuchic1.htm, 16. 2. 2018.)

\subsection{Sigurnost putnika}

Svaki dan velik broj ljudi pogine u prometnim nesrećama. Najčešće su te prometne nesreće uzrokovane ljudskim faktorom, odnosno, ljudskom pogreškom. Stoga bi jedna od karakteristika na koju treba obratiti pozornost pri dimenzioniranju novoga sustava javnog gradskog prijevoza trebala biti sigurnost samog putnika, ali i ostalih sudionika u prometu. Temeljna zadaća javnog gradskog prijevoza je da putnicima pruži pouzdanu i sigurnu uslugu. Kada se gleda s aspekta prometne infrastrukture PRT sustav vrlo je siguran jer su sva vozila na vodilicama koordinirana, stoga su sudari gotovo pa nemogući. S aspekta putnika, PRT je inherentno siguran zbog dvaju osnovnih razloga: vozilo se ne dijeli sa strancima i nemoguće je da vozilo zaluta na stanici, jer su prazna vozila na čekanju i čekaju putnike. Veliku razinu sigurnosti PRT sustav ostvaruje osiguravanjem videonadzora na stanicama i u dizalima sustava. Videonadzor nikada se ne bi trebao postavljati u vozila javnog gradskog prijevoza zbog intime korisnika sustava, stoga se ne postavlja ni u vozila PRT sustava. Jedinu prijetnju za putnika može predstaviti nasilan ulazak napadača u vozilo, stoga je svako vozilo opremljeno dvjema tipkama. Jedna tipka je „sljedeća stanica“ koja preusmjerava vozilo na prvu sljedeću stanicu, a ako se pritisne druga tipka, „hitna stanica", vozilo će nastaviti vožnju do prve hitne stanice gdje će putniku na raspolaganju stajati hitna pomoć i policija. Prilikom dolaska putnika na odredište vozilo se važe. Ako je u roku od 40 sekundi putnik i dalje u vozilu, vrata se zatvaraju i vozilo se preusmjerava na najbližu „hitnu stanicu“. Takav postupak osigurava brzu hitnu pomoć ako se dogodi da je putnik sam u vozilu, a pao je u nesvijest ili je došlo do nekoga drugog zdravstvenog problema. (Irving 1977:26)

\section{5 Odnos PRT-a i okoliša}

Atraktivni PRT sustav u urbanom području nudi brz i učinkovit prijevoz, no pored toga nudi i brojne ekološke prednosti. Glavne značajke pogonskog sustava kod PRT vozila su da nema ispušnih plinova koji zagađuju okolišs, a razina buke i vibracija smanjena je na minimum jer većina PRT sustava ima gumene gume koje se „kreću“ po betonu ili čeliku malom težinom i brzinom. PRT sustav je neprekidan, pa se malo energije troši na akceleraciju; sporiji je od ostalih sustava, pa se manje energije troši i na otpor vjetra. Očito je da sustavi imaju manje emisija jer koriste manje energije. Onima koji su električno pogonjeni, emisije su povezane s onima 
u elektrani koje su smještene obično izvan grada, no sustavi čak mogu biti povećani čistom energijom, odnosno mogu raditi na solarni sustav ili baterije (http://www.ultraglobalprt. com/the-benefits/environmental/, 5. 1. 2018.). Pored smanjenja potrošnje energije i pratećeg onečišćenja, povećanje produktivnosti resursa ključno je za dugoročnu održivost. PRT koristi manje resursa, a proizvode više rezultata od njih za razliku od drugih transportnih sustava. No, s obzirom na malu veličinu prijevoznog sredstava i visoku stopu popunjenosti, materijalni zahtjevi za vozila također su znatno manji od ostalih transportnih sustava. Može se, stoga, reći da PRT sustav ilustrira načela prirodnog kapitalizma.

PRT studije pokazuju da će mreža PRT sustava privući 20 - 50 \% turističkih putovanja u urbanom području, dok ostali sustavi privlače manje od $3 \%$, dakle i u tome segmentu je očito da PRT sustavi imaju prednost. (http://www.electric-bikes.com/prt.htm, 27. 12. 2017.).

\section{6 Grad Masdar}

Masdar je grad u Abu Dhabiju; osim što je to jedinstveni grad budućnosti koji je bogat naftom, to je i ekološki najčišći grad na svijetu. Kako bi potpuno eliminirali emisije $\mathrm{CO}_{2^{\prime}}$ grad je morao uvesti rigoroznu mjeru - zabranu osobnih automobila pokretanih motorima s unutarnjim izgaranjem. Stoga je Masdar nazivan prvim gradom potpuno oslobođenim od štetnih $\mathrm{CO}_{2}$ emisija. No, kako bi grad zadovoljio potrebu stanovništva za mobilnosti, Masdar je od studenog 2010. implementirao PRT sustav. Od 20. studenog 2010. do 22 svibnja 2014. PRT sustav prevezao je ukupno 2 milijuna putnika. PRT sustav radi 18 sati dnevno, od 06:00 do 00:00 h, svaki dan, i dosad nije imao niti jednu prometnu nesreću, a dostupnost sustava i pouzdanost vozila dosljedno premašuju 99,6 \% i 99,9 \%. Dosad je sustav prevezao znatno više putnika nego što je Grad očekivao, a svojim atraktivnim dizajnom i radom privlači i velik broj turističkih putovanja. Vozila rade uz pomoć litij-željezo-fosfatnom (LiFePO4) baterija i u pogonu su 18 sati dnevno. Pune se preko solarnih panela smještenih na krovovima grada Masdara (80V DC) ili iz mreže (400V AC) te preko platformi za punjenje. $U$ računicu se ubraja i rad klimatizacijskih uređaja u vozilima koji su prijeko potrebna zbog visokih temperatura u tom području. Prema tome se može zaključiti da je grad uz korištenje PRT sustava i dalje ostao čist grad od emisija $\mathrm{CO}_{2}$ a pri tome konstantno zadovoljava potrebu za mobilnosti ljudi i robe. Masdar je zbog svoje zanimljive priče ugostio velik broj poznatih osoba i političara, te je PRT sustav vjerojatno prevezao više važnih i poznatih putnika od bilo kojeg drugog javnog gradskog prijevoza na svijetu, a pritom se nikada nikome ništa nije desilo. Time je potkrijepio sve svoje, prethodno navedene, prednosti. (http://www.masdar.ae/en/masdar-city/ detail/masdar-transportation-competition, 5. 1. 2017.) 
Slika 5. PRT sustav u gradu Masdaru

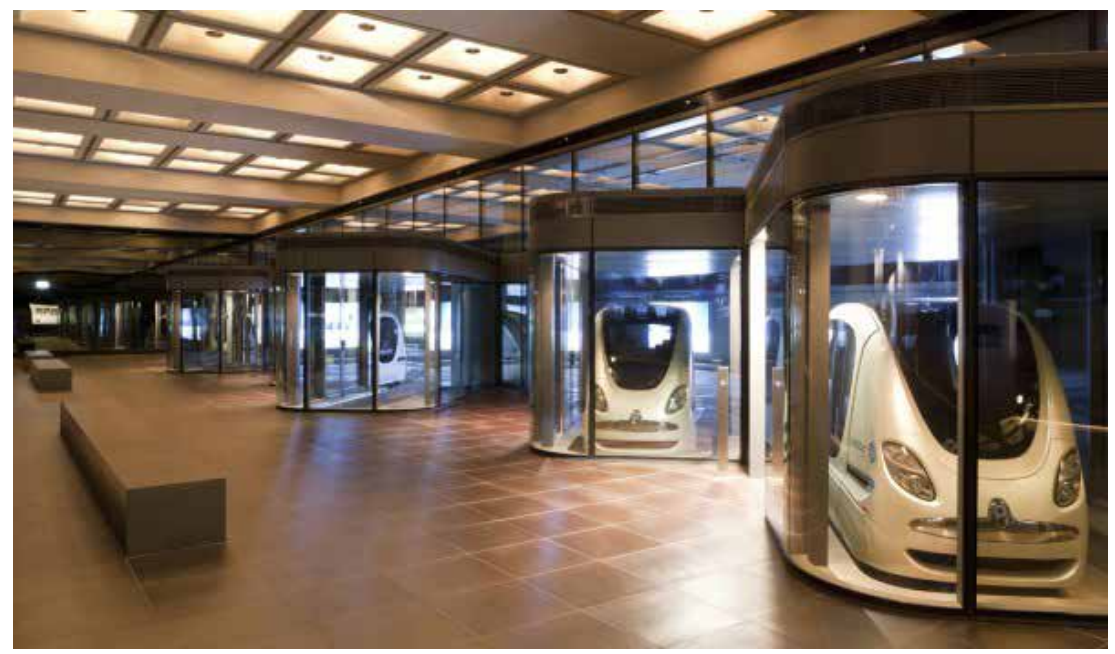

Izvor: www.masdar.ae, 28. 12. 2017.

\section{ZAKLJUČAK}

Zbog nepovoljnih čimbenika koje pruža današnji sustav javnog gradskog prijevoza, koji uključuju sve veća zagušenja, smanjenu mobilnost, ekološke čimbenike i nedovoljno atraktivan sustav, postoji potreba za implementiranje suvremenijeg sustava javnog gradskog prijevoza. Zanimljivo je da odgovor na navedene zahtjeve pruža sustav koji je izumljen davne 1964. godine. Sustav pod nazivom Personal Rapid Transit (PRT sustav) je zaboravljeni, atraktivni i alternativni javni prijevoz koji nadopunjuje klasične sustave javnog gradskog prijevoza pozitivnim čimbenicima koje nudi osobno vozilo, a da pritom ne zagađuje okoliš. Unatoč tome što je davno izumljen i odlikuje se brojnim pozitivnim referencama, PRT sustav je zahtijevao dug period kako bi se u potpunosti realizirao, a tome su pridonosili neki ključni nedostatci sustava. Među glavnim nedostatcima ističe se nedostatak prostora za izvođenje kompliciranih vodilica PRT sustava, a kao takvoga teško ga je implementirati u postojeću urbanu sredinu. Ne posjeduje ni nikakve regulatorne mjere za njegovo izvođenje. Navedeni problemi u kombinaciji s visokim troškovima gradnje uzrokovali su da od 1964. godine tek posljednjih par godina PRT sustav dosegne svoju operativnu stvarnost. No, unatoč navedenim preprekama, PRT sustav je dokazao da može funkcionirati kao glavni tranzitni sustav jedne nove urbane sredine, nadopuna ostalim tranzitnim sustavima te kao zaseban tranzitni sustav unutar zračnih luka, poslovnih centara, velikih avenija i sličnih sustava. Postojeći PRT sustavi pružaju tranzitno iskustvo koje oduševljava korisnike i svojom atraktivnošću, između ostalog, privlači velik broj turističkih putovanja. Tri osnovna proizvođača PRT sustava ULTra, 2getthere i Vectus spremni su ponuditi posebno dizajnirane, testirane i dokazane sustave za razvoj PRT-a za bilo koje urbano područje. Grad Masdar je primjer koji dokazuje da PRT sustav može biti rješenje suvremenih problema javnog gradskog prijevoza. PRT sustav u konačnici dokazuje da je sposoban uspostaviti bolju ravnotežu između prometne ponude i prometne potražnje, a da pritom poštuje glavne ciljeve održive mobilnosti. 


\section{LITERATURA}

Brčić D., Slavuj M. (2013) Planovi održive urbane mobilnosti - SUMP, Zagreb, Fakultet prometnih znanosti ,

Zagreb

Irving, J. H. (1977) Fundamentals of personal rapid transit, Massachusetts, Toronto

Štefančić, G. (2008) Tehnologija gradskog prometa I, Zagreb, Fakultet prometnih znanosti, Zagreb

Zanzerović Z., Savić, M. (2012) Ekološki aspekti usporedbe željezničkog i cestovnog prijevoza masovnog tereta,

Rijeka, Pomorski fakultet u Rijeci

www.michelin.com.hr/o/odrziva-mobilnost (10.10.2017.)

https://www.2getthere.eu/systems/personal-rapid-transit/ (22. 10. 2017.)

http://www.prtconsulting.com/benefits.html (15. 12. 2017.)

https://www.railway-technology.com/projects/personal-rapid-transit/ (19. 12. 2017.)

http://www.boeing.com/history/products/personal-rapid-transit-system.page (19. 12. 2017.)

https://www.2getthere.eu/systems/freight-rapid-transit/ (20. 12. 2017.)

http://www.ultraglobalprt.com/the-benefits/environmental/ (5. 1. 2018.)

http://www.electric-bikes.com/prt.htm (27. 12. 2017.)

http://www.masdar.ae/en/masdar-city/detail/masdar-transportation-competition (5. 1. 2017.)

http://www.faculty.washington.edu/jbs/itrans/vuchic1.htm (16. 2. 2018.) 


\title{
MAINTAINING SUSTAINABLE MOBILITY BY USING PERSONAL RAPID TRANSIT ${ }^{4}$
}

\begin{abstract}
There is no doubt about negative effects of traffic on the environment: it pollutes the air, the water, the soil, it raises the noise and vibration level, it leads to other climate changes and it also affects human health. The increasing number of motor vehicles makes these problems even worse every day. Therefore the priority for traffic organisation and urban environment lies in finding ways to reduce the number of vehicles on the roads with the purpose of reducing environment pollution, but also in keeping at the same time the reached mobility level of people and goods. One of the ways to achieve the balance between environmental pollution reducion and people and goods mobility level is Personal Rapid Transit (PRT). Personal Rapid Transit is an attractive public city transport system that enables constant people and goods mobility, from one spot to another, with minimal environmental pollution. So far this system has been implemented in several cities and it corrobates all its advantages. However, a lot of PRT systems have been proposed, but most of them, unfortunately, have not been implemented, even though PRT is a completely ecological transport system and has an enormous potencial for solving current transport problems. At the same time it is also quite complicated and easily misunderstood. PRT has not yet been put into practice and is not widely used therefore it is still relatively unknown, although it has the potential to change the transport system and public city transport history. The purpose of this article has been to show some positive sides of PRT system and to illustrate it with a concrete example of the city of Masdar where transport problems have been solved and environmental pollution reduced. The aim of the article is to show the PRT system as a new and attractive form of public transport.
\end{abstract}

Keywords: urban areas, environment, transport system, public transport

1 BEng in Traffic, Student, Polytechnic of Rijeka, Vukovarska 58, 51000 Rijeka, Croatia. E-mail: itomic@veleri.hr

2 Professional Specialist in Transport Engineering, Assistant, Polytechnic of Rijeka, Vukovarska 58, 51000 Rijeka, Croatia. E-mail: damir.pilepic@veleri.hr

3 PhD., College Professor, Polytechnic of Rijeka, Vukovarska 58, 51000 Rijeka, Croatia. E-mail: ivica.barisic@veleri.hr 